\title{
Nutritional characteristics of meat from lambs fed diets containing mulberry hay
}

\author{
L.G.A. Cirne ${ }^{1 \#}$, A.G.S. Sobrinho², E.A. Oliveira ${ }^{2}$, G.G.P. Carvalho ${ }^{3}$, G.M.B. Moreno ${ }^{4}$, \\ R.L. Valença ${ }^{2}$, F.A. Almeida ${ }^{2}$, V. Endo ${ }^{2}$ \& N.M.B.L. Zeola \\ ${ }^{1}$ Institute of Biodiversity and Forestry, Federal University of Western Pará. Santarém, Brazil \\ ${ }^{2}$ Department of Animal Science, São Paulo State University. Jaboticabal, Brazil \\ ${ }^{3}$ Department of Animal Science, Federal University of Bahia. Salvador, Brazil \\ ${ }^{4}$ Department of Animal Science, Federal University of Alagoas. Arapiraca, Brazil
}

(Received 4 June 2018; Accepted 23 August 2018; First published online 2 March 2019)

\author{
Copyright resides with the authors in terms of the Creative Commons Attribution 4.0 South African Licence. \\ See: http://creativecommons.org/licenses/by/4.0/za \\ Condition of use: The user may copy, distribute, transmit and adapt the work, but must recognise the authors and \\ the South African Journal of Animal Science.
}

\begin{abstract}
The objective of this study was to evaluate the nutritional characteristics of meat from lambs fed diets containing $0 \%, 12.5 \%$ and $25.0 \%$ (dry matter (DM)) mulberry hay as a substitute for the concentrate. Twentyfour feedlot Île-de-France lambs with an average age of 60 days and bodyweight (BW) of $15 \mathrm{~kg}$ were fed in individual stalls and slaughtered at $32 \mathrm{~kg} \mathrm{BW}$, at approximately 130 days old. The chemical composition of the experimental diets contained, respectively, 584.4, 569.4 and $571.8 \mathrm{~g} \mathrm{DM} / \mathrm{kg} ; 188.8,185.1$ and $184 \mathrm{~g}$ crude protein (CP)/kg and 29.9, 29.5 and $25.5 \mathrm{Mcal} / \mathrm{kg}$ DM for the mulberry hay inclusion levels of $0 \%$, $12.5 \%$ and $25.0 \%$, with a dietary forage to concentrate ratio of $50: 50$. The chemical composition of the meat was $757.9 \mathrm{~g}$ moisture $/ \mathrm{kg} \mathrm{DM}, 208.6 \mathrm{~g} \mathrm{CP} / \mathrm{kg} \mathrm{DM}, 22.9 \mathrm{~g}$ crude fat $/ \mathrm{kg} \mathrm{DM}$ and $10.5 \mathrm{~g}$ ash $/ \mathrm{kg} \mathrm{DM}$. Cholesterol concentration $(36.07 \mathrm{mg} / 100 \mathrm{~g})$ in the meat was not influenced by mulberry hay inclusion of the diet. An increase was observed in the concentrations of saturated pentadecanoic, heptadecanoic and arachidic acids; monounaturated heptadecenoic acid; and polyunsaturated $\alpha$-linolenic, $\gamma$-linolenic and eicosapentaenoic acids. Nervonic and conjugated linoleic acid (CLA) concentrations responded quadratically, representing $3.7 \mathrm{~g} / \mathrm{kg}$ and $5.9 \mathrm{~g} / \mathrm{kg}$ of the meat when mulberry hay was included at $16.98 \%$ and $12.56 \%$. Omega-3 acid concentrations increased, while the omega-3 : omega- 6 ratio decreased in the meat of mulberry hay-fed animals. Inclusion of mulberry hay in lamb diets increases the amount of desirable fatty acids in their meat, whose nutritional characteristics are improved.
\end{abstract}

Keywords: Chemical composition, fatty acids, feedlot, sheep meat

\# Corresponding author: Lgabrielcirne@hotmail.com

\section{Introduction}

Meat is considered a 'noble' food for humankind, as it contributes to the human diet with proteins, fat, minerals and vitamins, which are essential nutrients for life. At the present time, important changes are taking place in the eating habits of the world's population, who seeks healthier and better-quality products. Meats with these nutritional characteristics have become a preference because of their functional properties (Costa et al., 2008). In sheep meat, polyunsaturated fatty acids (PUFAs) recognized as beneficial to human health such as linoleic (omega-6) and linolenic (omega-3) acids can compose up to $72 \%$ of desirable fatty acids (Banskalieva et al., 2000).

The feedlot is an alternative system for finishing lambs in which the animal reaches the degrees of conformation and fatness required for slaughter in a short period, providing high-quality standardized carcasses. One of the obstacles in this method is the cost of feed, which often raises the cost of the production system. Conventional sources of energy and protein such as soybean meal and corn grain elevate feed costs greatly. Using different protein and energy sources are thus an interesting option for the production chain, provided that they do not compromise animal performance or final product quality.

Many authors have investigated the use of mulberry (Morus sp.) in ruminant nutrition (Kandylis et al., 2009; Vu et al., 2011). However, most studies evaluate performance data without addressing qualitative aspects of the meat, although both factors are greatly influenced by the diet. 
Mulberry (Morus sp.), a member of the family, Moraceae, is used as a forage ingredient in ruminant feeding by virtue of its grass-like features such as adaptation to different soils and climates, biomass yield of 25 to 30 t/ha/yr, crude protein (CP) levels of $18 \%$ to $28 \%$, total digestible nutrients content of $76 \%$, good acceptance by animals and a dry matter (DM) digestibility of 75\% to 85\% (Sanchez, 2002; Ba et al., 2005; Bamikole et al., 2005). These properties render this plant a potential alternative feedstuff in ruminant diets.

Given the importance of nutrition in production and general aspects of meat, research should be undertaken to discover alternative feedstuffs that can improve quality traits in sheep meat. The consumption of lamb meat of higher nutritional quality can deliver benefits to human health. On this basis, this study was developed to evaluate the nutritional characteristics of meat from lambs fed diets containing mulberry hay.

\section{Materials and Methods}

The study complied with the Ethical Principles of Animal Experimentation adopted by the Brazilian College of Animal Experimentation (COBEA) and was approved by the Ethics Committee in Animal Use (CEUA) of the Faculty of Agriculture and Veterinary Sciences, FCAV - UNESP, Protocol 014105/11.

The experiment was conducted at the Sheep Husbandry Section in the Department of Animal Science, Faculty of Agriculture and Veterinary Sciences, FCAV - UNESP, in Jaboticabal - SP, Brazil. Twenty-four weaned Île-de-France lambs at approximately 60 days old, with an initial body weight (BW) of $15.48 \pm 0.07 \mathrm{~kg}$, were housed in a shed in individual pens $\left(1 \mathrm{~m}^{2}\right)$ on a raised wooden slatted floor, equipped with individual feeders and water troughs. At the beginning of the experiment, lambs were identified, dewormed, vaccinated against clostridial diseases, supplemented with vitamins A, D and E, and randomly allotted to the treatments.

Experimental diets (Table 1) were formulated to meet the requirements of weaned lambs with an average weight gain of $300 \mathrm{~g} /$ day, as suggested by the National Research Council (2007). The percentages of the main fatty acids in the concentrates and in the ingredients (Table 2) were determined according to methodologies proposed by Bligh \& Dyer (1959) and ISO (1978), as detailed below in the analysis of meat.

The forage to concentrate ratio in the diets was $50: 50$. Dietary treatments were: sugarcane + concentrate without mulberry hay; sugarcane + concentrate containing $12.5 \%$ mulberry hay; and sugarcane + concentrate with $25.0 \%$ mulberry hay. Mulberry hay substituted corn grain in the experimental diets. The sugarcane was variety IAC 86-2480, which was chopped to a particle size of approximately $1.0 \mathrm{~cm}$ and was provided fresh. The mulberry branches, obtained from the Department of Sericulture at FCAV-UNESP, were cut after 60 days of regrowth and sundried until reaching the point of hay, below $20 \%$ moisture. Once hayed, the material was ground using a $0.8-\mathrm{mm}$ sieve to improve the homogeneity of the concentrate ingredients and to prevent animal selectivity.

The feed was supplied at 7:00 and at 17:00 to ensure at least 10\% as orts, and fresh feed and orts were weighed daily to determine DM intake. Animals were weighed every 14 days to determine their weight gain. On reaching $32.2 \pm 0.49 \mathrm{~kg} \mathrm{BW}$, lambs underwent a water-only diet for 16 hours. The slaughtering procedures began with stunning with a 220-W electric discharge for two seconds followed by bleeding by sectioning the jugular veins and carotid arteries. After skinning, evisceration and removal of head and limbs, carcasses were moved to a cold-storage room at $6{ }^{\circ} \mathrm{C}$, where they remained for 24 hours, hanging by the gastrocnemius tendons on appropriate hooks spaced $17 \mathrm{~cm}$ apart.

The carcasses were then split lengthwise into two half-carcasses. The left half was sectioned into five anatomical regions: neck, shoulder, rib, loin and leg. Longissimus lumborum muscles were identified individually, vacuum packed and stored at $-18{ }^{\circ} \mathrm{C}$ until analysis.

For the analysis of the samples, the loins were thawed inside plastic bags in a biochemical oxygen demand (BOD) incubator at $10^{\circ} \mathrm{C}$ for 12 hours and dissected with a scalpel and a knife. Longissimus lumborum samples were harvested to determine the chemical composition, cholesterol concentration and fatty acid profile.

For the chemical composition, samples were lyophilized for 72 hours and then ground through a ball mill to generate the laboratory sample. The chemical composition of the meat was determined in moisture, $\mathrm{CP}$, crude fat and mineral contents, following the methodology proposed by AOAC (1995).

The meat cholesterol concentration was obtained according to the methodology of Bohac et al. (1988). For this, lipid extraction was carried out using a $2: 1$ ratio of chloroform to methanol in a 10-g raw sample of the longissimus lumborum muscle. Subsequently, $5 \mathrm{~mL}$ of the chloroform extract was evaporated with nitrogen gas and subjected to saponification with potassium hydroxide in $12 \%$ ethanol. The unsaponifiable fraction (cholesterol) was extracted with hexane, purified and subjected to a colour reaction using acetic and sulphuric acids and ferrous sulphate as the catalyst. Absorbance was then determined with a spectrophotometer at $490 \mathrm{~nm}$. The calibration curve for cholesterol was established using $0.01 \mathrm{~g}$ of p.a. cholesterol diluted in $50 \mathrm{~mL}$ hexane, and aliquots of 40,80, 120, 160 and $200 \mathrm{mg} / \mathrm{mL}$ were taken. 
Table 1 Chemical composition of ingredients and experimental diets containing mulberry hay

\begin{tabular}{lccc}
\hline \multirow{2}{*}{ Diet composition (g/kg) } & \multicolumn{3}{c}{ Mulberry hay (\%) } \\
\cline { 2 - 4 } & $\mathbf{0}$ & $\mathbf{1 2 . 5}$ & $\mathbf{2 5 . 0}$ \\
\hline Sugar cane & 500 & 500 & 500 \\
Mulberry hay & - & 125.0 & 250.0 \\
Soybean meal & 284.9 & 246.0 & 213.3 \\
Ground corn grain & 178.0 & 90.0 & 0.00 \\
Soybean oil & 10.0 & 10.0 & 10.0 \\
Urea & 8.0 & 8.0 & 8.0 \\
Vitamin and mineral supplement ${ }^{1}$ & 5.0 & 5.0 & 5.0 \\
Calcitic limestone $_{\text {Dicalcium phosphate }}$ & 4.7 & 4.3 & 2.5 \\
Chemical composition & 9.4 & 11.7 & 11.2 \\
Dry matter & & & \\
Organic matter $^{2}$ & 584.4 & 569.4 & 571.8 \\
Mineral matter $^{2}$ & 936.3 & 925.6 & 919.2 \\
Crude protein $^{2}$ & 41.7 & 49.9 & 58.7 \\
Ether extract $^{2}$ & 188.8 & 185.1 & 184.0 \\
Lignin $^{2}$ & 28.8 & 25.5 & 22.1 \\
Neutral detergent fibre $^{2}$ & 20.7 & 21.9 & 23.2 \\
Acid detergent fibre $^{2}$ & 235.6 & 242.6 & 250.1 \\
Total carbohydrates $^{2}$ & 146.6 & 158.4 & 170.6 \\
Non-fibrous carbohydrate $^{2}$ & 732.7 & 729.5 & 727.6 \\
Metabolizable energy (Mcal/kg DM) & 497.1 & 486.8 & 477.5 \\
\hline & 29.9 & 29.5 & 25.5 \\
\hline
\end{tabular}

Table 2 Percentage compositions of fatty acids of diets containing mulberry hay and of the ingredients used in the diets

\begin{tabular}{|c|c|c|c|c|c|c|c|}
\hline \multirow{2}{*}{ Fatty acid $(\mathrm{g} / \mathrm{kg})$} & & \multicolumn{3}{|c|}{ Mulberry hay (\%) } & \multirow{2}{*}{$\begin{array}{l}\text { Mulberry } \\
\text { hay }\end{array}$} & \multirow{2}{*}{$\begin{array}{c}\text { Soybean } \\
\text { meal }\end{array}$} & \multirow{2}{*}{$\begin{array}{c}\text { Ground } \\
\text { corn }\end{array}$} \\
\hline & & 0 & 12.5 & 25 & & & \\
\hline Caprylic & C8:0 & 0.3 & 0.8 & 1.2 & 1.4 & 0.5 & - \\
\hline Myristic & C14:0 & 0.7 & 2.0 & 2.5 & 4.7 & 1.0 & 0.6 \\
\hline Palmitic & C16:0 & 143.5 & 171.1 & 206.2 & 241.0 & 188.0 & 120.0 \\
\hline Heptadecanoic & C17:0 & 0.9 & 2.1 & 2.7 & 6.2 & 1.2 & 0.8 \\
\hline Stearic & C18:0 & 30.4 & 36.8 & 39.9 & 45.4 & 37.4 & 32.3 \\
\hline Palmitoleic & C16:1 & 1.2 & 1.4 & 1.1 & 29.0 & 1.2 & 1.2 \\
\hline Oleic & C18:1w9 & 281.5 & 209.0 & 143.7 & 23.0 & 158.5 & 292.4 \\
\hline Linoleic & C18:2w6 & 442.7 & 442.4 & 401.8 & 105.4 & 529.8 & 489.3 \\
\hline$\gamma$-linolenic & C18:3w6 & 0.3 & 0.9 & 1.6 & 2.1 & - & 0.3 \\
\hline a-linolenic & C18:3w3 & 24.3 & 101.3 & 166.0 & 504.3 & 55.6 & 40.00 \\
\hline
\end{tabular}

The total lipids of the longissimus lumborum muscle were extracted according to the methodology described by Bligh \& Dyer (1959). Afterwards, triacylglycerols were transesterified using method 5509 of ISO (1978) in n-heptane and $\mathrm{KOH} /$ methanol solution. The fatty acid esters were isolated and analysed in a Shimadzu 14B gas chromatograph equipped with a flame ionization detector and a fused silica capillary 
column (30 m length, $0.25 \mathrm{~mm}$ internal diameter and $0.25 \mu \mathrm{m}$ Omega wax 250). The initial column flame temperature was $50{ }^{\circ} \mathrm{C}$, which was held for $2 \mathrm{~min}$ and raised to $220^{\circ} \mathrm{C}$ at $4{ }^{\circ} \mathrm{C} / \mathrm{min}$ for $25 \mathrm{~min}$. Methyl ester standards were obtained from Sigma-Aldrich, and data were expressed as percentage compositions of each fatty acid.

Desirable fatty acid (DFA) concentrations were determined according to Rhee (1992). The $\Delta^{9}$ desaturase and elongase enzyme activities were calculated according to methods described by MalauAduli et al. (1997) and Kazala et al. (1999). Atherogenicity index (Al) and thrombogenicity index (TI) were determined following Ulbricht \& Southgate (1991). The hypocholesterolemic to hypercholesterolemic $(\mathrm{h}: \mathrm{H})$ ratio and the concentrations of hypercholesterolemic, hypocholesterolemic and neutral fatty acids were calculated as described by Bessa (1999) and Santos-Silva et al. (2002).

Calculations were made using these equations: DFA = MUFA + PUFA + C18:0; $\Delta^{9}$ desaturase $16=$ $100\left[\left(\mathrm{C} 16: 1\right.\right.$ cis9)/(C16:1cis9 + C16:0)]; $\Delta^{9}$ desaturase $18=100$ [(C18:1cis9)/(C18:1cis9 + C18:0)]; elongase $=100[(\mathrm{C} 18: 0+\mathrm{C} 18: 1$ cis 9$) /(\mathrm{C} 16: 0+\mathrm{C} 16: 1$ cis9 + C18:0 + C18:1cis9) $]$; atherogenicity index: $[\mathrm{C} 12: 0+$ $4(\mathrm{C} 14: 0)+\mathrm{C} 16: 0] / \Sigma$ UFA; thrombogenicity index: $(\mathrm{C} 14: 0+\mathrm{C} 16: 0+\mathrm{C} 18: 0) /[(0.5 \times \Sigma$ MUFA $)+(0.5 \times \Sigma \omega 6+(3$ $\times \Sigma \omega 3)+(\Sigma \omega 3 / \Sigma \omega 6)] ;$ h:H ratio: hypocholesterolemic/hypercholesterolemic fatty acids; hypocholesterolemic fatty acids: $\mathrm{C} 18: 1 \omega 7+\mathrm{C} 18: 1 \omega 9+\mathrm{C} 18: 2 \omega 6+\mathrm{C} 18: 3 \omega 3+\mathrm{C} 18: 3 \omega 6+\mathrm{C} 20: 3 \omega 6+\mathrm{C} 20: 5 \omega 3$; hypercholesterolemic fatty acids: C12:0 + C14:0 + C14:1 + C16:0 + C16:1; and neutral fatty acids: C10:0 + C18:0.

A completely randomized design was adopted for three treatments with eight replicates, totalling 24 experimental units. Results were assessed by analyses of variance and regression, with degrees of freedom decomposed into linear or quadratic effects, according to the percentages of mulberry hay. The significance of regressions was obtained by the F-test at the $1 \%$ or $5 \%$ probability levels using the Sisvar statistical programme (Ferreira, 2011).

\section{Results and Discussion}

There were no alterations $(P>0.05)$ in chemical composition or cholesterol levels of the meat from mulberry hay-fed lambs in comparison with the meat from control-fed lambs (Table 3).

Table 3 Chemical composition and cholesterol levels of the longissimus lumborum muscle from lambs fed diets containing mulberry hay

\begin{tabular}{|c|c|c|c|c|c|c|}
\hline \multirow{2}{*}{ Item (g/kg) } & \multicolumn{3}{|c|}{ Mulberry hay (\%) } & \multicolumn{2}{|c|}{$P$-value ${ }^{1}$} & \multirow{2}{*}{ CV (\%) } \\
\hline & 0 & 12.5 & 25.0 & $\mathbf{L}$ & $\mathbf{Q}$ & \\
\hline Moisture & 756.8 & 760.9 & 756.0 & 0.805 & 0.374 & 2.01 \\
\hline Protein & 211.0 & 202.5 & 212.4 & 0.924 & 0.311 & 7.51 \\
\hline Fat & 21.4 & 26.1 & 21.3 & 0.960 & 0.167 & 28.20 \\
\hline Ash & 10.8 & 10.5 & 10.3 & 0.571 & 0.948 & 12.06 \\
\hline Cholesterol $^{3}$ & 34.17 & 37.78 & 36.26 & 0.545 & 0.394 & 14.70 \\
\hline
\end{tabular}

\footnotetext{
${ }^{1}$ Effect: L: linear; Q: quadratic

${ }^{2} \mathrm{CV}$ : coefficient of variation

${ }^{3} \mathrm{mg} / 100 \mathrm{~g}$ meat
}

The chemical compositions observed in this study (Table 3) were in agreement with those observed in sheep meat by Tornberg (2005), which included $75 \%$ moisture, $20 \%$ CP, 3\% crude fat and $2 \%$ non-protein substances (vitamins, minerals, carbohydrates, among others). The cholesterol level in the sheep meat observed in this trial is considered low $(<90 \mathrm{mg} / 100 \mathrm{~g})$, according to Madruga et al. (2008), characterizing the meat as a healthy food.

Inclusion of mulberry hay $(12.5 \%$ and $25.0 \%)$ modified $(P<0.05)$ the fatty acid profile of lamb meat (Table 4) and increases $(P<0.05)$ were observed in the concentrations of the saturated pentadecanoic, heptadecanoic and arachidic acids; the monounsaturated heptadecenoic acid; and the polyunsaturated a-linolenic, $y$-linolenic and eicosapentaenoic acids. Importantly, the concentrations of nervonic acid and conjugated linoleic acid (CLA) had a quadratic response $(P<0.05)$ to the treatments, with observed values of 3.7 and $5.9 \mathrm{~g} / \mathrm{kg}$ at the mulberry hay inclusion levels of $16.98 \%$ and $12.56 \%$, respectively. 
Table 4 Fatty acid profile of the longissimus lumborum muscle of lambs fed diets containing mulberry hay

\begin{tabular}{|c|c|c|c|c|c|c|c|}
\hline \multirow{2}{*}{ Fatty acid (g/kg) } & & \multicolumn{3}{|c|}{ Mulberry hay (\%) } & \multicolumn{2}{|c|}{$P$-value ${ }^{1}$} & \multirow{2}{*}{ CV $(\%)^{2}$} \\
\hline & & 0 & 12.5 & 25.0 & L & Q & \\
\hline \multicolumn{8}{|l|}{ Saturated } \\
\hline Capric & C10:0 & 1.2 & 1.2 & 1.3 & 0.234 & 0.988 & 16.31 \\
\hline Lauric & C12:0 & 1.1 & 1.6 & 1.2 & 0.691 & 0.130 & 48.60 \\
\hline Myristic & C14:0 & 23.3 & 23.9 & 23.7 & 0.889 & 0.893 & 22.38 \\
\hline Pentadecanoic $^{3}$ & $\mathrm{C} 15: 0$ & 3.1 & 4.1 & 4.2 & 0.008 & 0.146 & 14.07 \\
\hline Palmitic & C16:0 & 249.0 & 239.4 & 251.6 & 0.767 & 0.163 & 5.81 \\
\hline Heptadecanoic ${ }^{4}$ & C17:0 & 11.5 & 14.9 & 16.2 & 0.001 & 0.277 & 12.51 \\
\hline Stearic & C18:0 & 182.2 & 179.5 & 179.4 & 0.828 & 0.903 & 12.00 \\
\hline Arachidic $^{5}$ & C20:0 & 1.2 & 1.2 & 1.3 & 0.020 & 0.306 & 6.79 \\
\hline \multicolumn{8}{|l|}{ Monounsaturated } \\
\hline Myristoleic & C14:1 & 0.6 & 0.5 & 0.6 & 0.692 & 0.494 & 48.38 \\
\hline Palmitoleic & C16:1 & 16.6 & 14.6 & 15.4 & 0.415 & 0.288 & 15.54 \\
\hline Heptadecenoic $^{6}$ & C17:1 & 7.0 & 8.6 & 9.2 & 0.030 & 0.537 & 18.29 \\
\hline Oleic & C18:1w9 & 406.4 & 402.5 & 393.0 & 0.285 & 0.796 & 5.04 \\
\hline Cis-vaccenic & 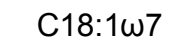 & 21.2 & 21.6 & 22.2 & 0.377 & 0.901 & 8.33 \\
\hline Eicosenoic & C20:1w9 & 0.8 & 0.9 & 0.8 & 0.858 & 0.579 & 17.28 \\
\hline Nervonic ${ }^{7}$ & $\mathrm{C} 24: 1 \omega 9$ & 2.0 & 3.6 & 3.3 & 0.015 & 0.043 & 26.33 \\
\hline \multicolumn{8}{|l|}{ Polyunsaturated } \\
\hline Linoleic & C18:2w6 & 42.8 & 47.5 & 43.5 & 0.891 & 0.305 & 17.59 \\
\hline$\alpha$-linolenic ${ }^{8}$ & C18:3w3 & 1.8 & 4.4 & 5.7 & 0.000 & 0.235 & 24.97 \\
\hline$\gamma$-linolenic ${ }^{9}$ & $\mathrm{C} 18: 3 \omega 6$ & 1.2 & 1.4 & 1.5 & 0.001 & 0.210 & 9.87 \\
\hline $\mathrm{CLA}^{10}$ & C18:2c9.t11 & 5.0 & 5.9 & 5.0 & 0.970 & 0.031 & 13.71 \\
\hline Eicosadienoic & $\mathrm{C} 20: 2$ & 0.4 & 0.4 & 0.4 & 0.741 & 0.621 & 22.74 \\
\hline Eicosatrienoic & C20:3w6 & 1.6 & 1.7 & 1.5 & 0.557 & 0.448 & 23.33 \\
\hline Arachidonic & 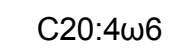 & 16.7 & 16.4 & 14.9 & 0.450 & 0.769 & 23.69 \\
\hline Eicosapentaenoic ${ }^{11}$ & $\mathrm{C} 20: 5 \omega 3$ & 0.8 & 1.7 & 1.7 & 0.015 & 0.149 & 38.65 \\
\hline Docosatetranoic & $\mathrm{C} 22: 4 \omega 6$ & 1.5 & 1.3 & 1.3 & 0.394 & 0.872 & 30.30 \\
\hline Docosahexaenoic & $\mathrm{C} 22: 6 \omega 3$ & 0.5 & 0.8 & 0.6 & 0.741 & 0.075 & 51.33 \\
\hline
\end{tabular}

\footnotetext{
${ }^{1}$ Effect: L: linear and Q: quadratic; ${ }^{2} \mathrm{CV}$ : coefficient of variation

${ }^{3} Y=0.332500+0.003933 x, R^{2}=0.80 \quad(x=$ mulberry hay level $)$

${ }^{4} Y=1.191222+0.018533 x, R^{2}=0.93$

${ }^{5} Y=0.118444+0.000533 x, R^{2}=0.85$

${ }^{6} Y=0.719833+0.008733 x, R^{2}=0.93$

${ }^{7} Y=0.208333+0.019707 x-0.000580 x^{2}, R^{2}=0.60$

${ }^{8} \mathrm{Y}=0.197667+0.015867 \mathrm{x}, \mathrm{R}^{2}=0.96$

${ }^{9} Y=0.123111+0.001333 x, R^{2}=0.90$

${ }^{10} Y=0.505000+0.014493 x-0.000577 x^{2}, R^{2}=1.00$

${ }^{11} \mathrm{Y}=0.095722+0.003533 \mathrm{x}, \mathrm{R}^{2}=0.76$

CLA: conjugated linoleic acid
}

The observed increases in the concentrations of heptadecanoic fatty acid with an increase in mulberry hay in the diet can be attributed to its high percentage in the composition of mulberry hay (Table 2). Pentadecanoic (C15:0) and heptadecanoic (C17:0) acids, two odd-chain fatty acids rarely found in the majority of mammals, are found at high concentrations in ruminants (Fernandes et al., 2009). Stearic acid (C18:0) is considered a neutral acid, unlike the saturated myristic (C14:0) and palmitic (C16:0) acids, which 
are the most hypercholesterolemic, as they reduce the activities of the hepatic receptors for low-density lipoprotein (LDL), as reported by Scollan et al. (2006).

The increased levels of $\alpha$-linolenic $(\omega 3)$ and $\gamma$-linolenic $(\omega 6)$ acids in the lamb meat might also have stemmed from the higher percentage of these acids in the mulberry hay that possibly escaped rumen fermentation. a-linolenic acid is a precursor of eicosapentaenoic acid, which was likewise found to increase in the meat of the animals. $y$-linolenic acid, in turn, is a precursor of dihomo-gamma-linolenic acid, which, despite not having been studied here, is a precursor of arachidonic acid (Perini et al., 2010). Eicosapentaenoic and arachidonic acids are precursors of eicosanoids (prostaglandins, thromboxanes and leukotrienes), inflammatory mediators of lipid origin that regulate and protect the organism against effects such as platelet aggregation (by virtue of their anti-thrombotic action). They also control blood pressure and inflammation and reduce immune responses. Arachidonic acid also acts on reproductive function, foetal growth and cerebral and retinal development. Additionally, eicosapentaenoic and arachidonic acids participate in a number of other processes important for human health (Yu \& Funk, 2006; Perini et al., 2010), imparting functional properties to the meat of lambs fed mulberry hay.

The increasing concentrations of polyunsaturated a-linolenic $(\omega-3)$ and $\gamma$-linolenic $(\omega-6)$ acids are related to their higher concentrations in mulberry hay (Table 2). The increased CLA concentration in the meat from animals fed diets containing $12.5 \%$ mulberry hay is probably due to the increase in dietary linoleic acid, since CLA derives from the partial biohydrogenation of this fatty acid in the rumen resulting from the microbial fermentation of Butyrivibrio fibrisolvents (Jenkins et al., 2008). This assertion is based on the increased contents of linoleic acid found in the lamb meat (Table 4).

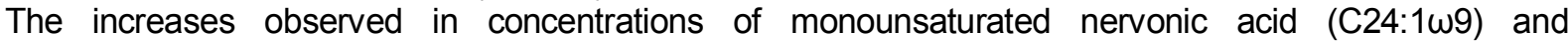

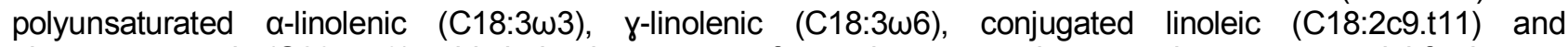
eicosapentaenoic (C20:5 $\mathrm{\omega} 3)$ acids in lamb meat are of great importance because they are essential for human health, with proven properties against the development of carcinogenesis, diabetes, atherosclerosis and thrombotic disease (Willians, 2000; Mulvihill, 2001; Belury, 2002).

Saturated (SFA), unsaturated (UFA), monounsaturated (MUFA), polyunsaturated (PUFA) and desirable fatty acid (DFA) concentrations as well as UFA to SFA, MUFA to SFA, PUFA to SFA, and (C18:0 + C18:1) to C16:0 ratios were not altered in the meat from lambs fed mulberry hay $(P>0.05)$ (Table 5).

Table 5 Concentrations and ratios of fatty acids in the longissimus lumborum muscle of lambs fed diets containing mulberry hay

\begin{tabular}{|c|c|c|c|c|c|c|}
\hline \multirow{2}{*}{ Variable } & \multicolumn{3}{|c|}{ Mulberry hay (\%) } & \multicolumn{2}{|c|}{ P-value ${ }^{1}$} & \multirow{2}{*}{$\mathrm{CV}(\%)^{2}$} \\
\hline & 0 & 125 & 250 & $\mathbf{L}$ & $\mathbf{Q}$ & \\
\hline SFA (g/kg DM) & 472.8 & 465.9 & 479.0 & 0.615 & 0.358 & 4.30 \\
\hline UFA (g/kg DM) & 527.2 & 534.0 & 520.9 & 0.615 & 0.358 & 3.86 \\
\hline MUFA (g/kg DM) & 452.8 & 448.8 & 441.4 & 0.414 & 0.887 & 5.06 \\
\hline PUFA (g/kg DM) & 74.4 & 85.2 & 79.5 & 0.500 & 0.216 & 15.65 \\
\hline DFA (g/kg DM) & 756.8 & 768.5 & 752.6 & 0.757 & 0.258 & \\
\hline UFA : SFA & 1.12 & 1.15 & 1.09 & 0.619 & 0.375 & 8.35 \\
\hline MUFA : SFA & 0.96 & 0.97 & 0.93 & 0.529 & 0.620 & 9.11 \\
\hline PUFA : SFA & 0.16 & 0.18 & 0.17 & 0.767 & 0.196 & 16.53 \\
\hline$(\mathrm{C} 18: 0+\mathrm{C} 18: 1): \mathrm{C} 16: 0$ & 2.46 & 2.52 & 2.37 & 0.513 & 0.351 & 8.83 \\
\hline Omega-3 (g/kg DM) $)^{3}$ & 3.1 & 6.9 & 8.0 & 0.000 & 0.082 & 23.95 \\
\hline Omega-6 (g/kg DM) & 63.8 & 68.3 & 62.7 & 0.873 & 0.405 & 17.76 \\
\hline Omega- 6 : Omega- $3^{4}$ & 20.99 & 10.07 & 8.06 & 0.000 & 0.022 & 25.33 \\
\hline
\end{tabular}

\footnotetext{
${ }^{1}$ Effect: L - linear; $\mathrm{Q}$ - quadratic; ${ }^{2} \mathrm{CV}$ : coefficient of variation

${ }^{3} Y=0.356056+0.009833 x, R^{2}=0.90(x=$ mulberry hay level $)$

${ }^{4} Y=19.505167-0.258567 x, R^{2}=0.86$

SFA: saturated fatty acid; UFA: unsaturated fatty acid; MUFA: monounsaturated fatty acid; PUFA: polyunsaturated fatty acid; DFA: desirable fatty acid; UFA : SFA: unsaturated fatty acid to saturated fatty acid; MUFA : SFA: monounsaturated fatty acid to saturated fatty acid; PUFA : SFA: polyunsaturated fatty acid to saturated fatty acid
} 
The DFA concentrations of $768.5 \mathrm{~g} / \mathrm{kg}$ DM and $752.6 \mathrm{~g} / \mathrm{kg} \mathrm{DM}$ in the meat of lambs fed $12.5 \%$ and $25.0 \%$ mulberry hay, respectively, are higher than the $64 \%$ to $72 \%$ reported by Rhee (1992) and Banskalieva et al. (2000). The PUFA to SFA ratio (0.18 and 0.17) and (C18:0 + C18:1):C16:0 ratio (2.52 and 2.37) were near the ranges of 0.07 to 0.26 and 2.1 to 2.8, respectively, reported by Rhee (1992) and Banskalieva et al. (2000). The latter ratio provides the best description of the possible beneficial effects of red-meat lipids, considering that these are major fatty acids, as represented by the neutrality of the C18:0 ratio, the beneficial effects of the C18:1 ratio and the detrimental effect of the C16:0 ratio (Bonanome \& Grundy, 1988).

An increase was observed in the percentage of omega-3 fatty acids $(P<0.01)$ (Table 5), which was mainly the result of the higher concentration of a-linolenic acid in the meat of lambs fed diets containing mulberry hay (Table 4). Although the concentration of omega-3 fatty acids in the meat of the animals studied here was small, these acids play a role in elevating the 'good' cholesterol, represented by the high-density lipoproteins (HDL). Higher percentages of omega-3 in the diet reduce cardiovascular risks (Simopoulos, 2002), which suggests that the meat of mulberry hay-fed lambs may be a healthy human foodstuff. Omega-3 fatty acids are essential because the human body is incapable of synthesizing them and, therefore, they must be incorporated in the diet. Long-chain fatty acids such as eicosapentaenoic and docosahexaenoic acids, in turn, are synthesized by the body (Coletta et al., 2010).

Although some PUFAS were present in high levels in the diets (Table 2), as were linoleic ( $\omega 6)$ and $\alpha$-linoleic ( $\omega 3)$ acids, which are the main fatty acids in ruminant feeding, their deposition in the lamb meat was low. This was probably a result of the biohydrogenation of these acids occurring during rumen fermentation, a process from which only $10 \%$ to $35 \%$ of the PUFAs escapes (Medeiros et al., 2015).

The omega- 6 to omega-3 ratio in the meat of mulberry hay-fed lambs decreased $(P<0.01)$, ranging from 20.99 (control treatment) to 8.06 (inclusion of $25.0 \%$ DM mulberry hay). Nutritionists have emphasized the importance of keeping the omega- 6 to omega-3 ratio lower than 4 to reduce coronary complications, and the ratio of $4: 1$ was associated with a 70\% decrease in total mortality (Simopoulos, 2004). However, most foodstuffs in the human diet have omega- 6 to omega-3 ratios higher than these values.

The activities of desaturase and elongase enzymes, Al and TI indices, hypocholesterolemic to hypercholesteraemic $(\mathrm{h}: \mathrm{H})$ ratios, and concentrations of hypercholesterolemic, hypocholesterolemic and neutral fatty acids of the meat of lambs fed diets containing mulberry hay were similar $(P>0.05)$ to those of the meat of animals receiving the control diet (Table 6).

Table 6 Enzyme activities and indices in the longissimus lumborum muscle of lambs fed diets containing mulberry hay

\begin{tabular}{|c|c|c|c|c|c|c|}
\hline \multirow{2}{*}{ Variable (\%) } & \multicolumn{3}{|c|}{ Mulberry hay (\%) } & \multicolumn{2}{|c|}{$P$-value ${ }^{1}$} & \multirow{2}{*}{ CV (\%) } \\
\hline & 0 & 125 & 250 & $\mathbf{L}$ & Q & \\
\hline$\Delta^{9}$ desaturase 16 & 6.25 & 5.75 & 5.76 & 0,302 & 0,531 & 12,97 \\
\hline$\Delta^{9}$ desaturase 18 & 69.05 & 69.13 & 68.75 & 0,877 & 0,895 & 4,75 \\
\hline Elongase & 68.90 & 69.61 & 69.16 & 0,533 & 0,297 & 2,82 \\
\hline Atherogenicity & 0.65 & 0.63 & 0.67 & 0,562 & 0,283 & 11,30 \\
\hline Thrombogenicity & 1.79 & 1.68 & 1.74 & 0,766 & 0,474 & 8,11 \\
\hline Hypocholesterolemic & 47.47 & 47.93 & 46.77 & 0,541 & 0,288 & 9,52 \\
\hline Hypercholesterolemic & 29.06 & 28.01 & 29.26 & 0,869 & 0,289 & 7,02 \\
\hline $\mathrm{h}: \mathrm{H}$ ratio & 1.73 & 1.80 & 1.64 & 0,544 & 0,421 & 4,01 \\
\hline Neutral fatty acids & 18.34 & 18.07 & 18.02 & 0,837 & 0,903 & 11,87 \\
\hline
\end{tabular}

${ }^{1}$ Effect: L: linear; Q: quadratic; ${ }^{2} \mathrm{CV}$ : coefficient of variation

$\mathrm{h}: \mathrm{H}$ ratio: hypocholesterolemic to hypercholesteraemic ratio

The desaturase enzyme activities in the meat of lambs fed diets containing mulberry hay were similar to those observed in the meat of those fed the control diet (Table 6). According to Malau-Aduli et al. (1997), the $\Delta^{9}$ desaturase 16 and 18 enzymes are responsible for the desaturation of SFAs with 16 and 18 carbons and convert these into their monounsaturated counterparts, with a double bond in carbon 9 . The mulberry hay-containing diets probably did not facilitate the formation of MUFAs (C16:1 and C18:1) from the 
desaturation of saturated acids (C16:0 and C18:0), since no changes were observed in these percentages (Table 4).

The $\mathrm{Al}$ and $\mathrm{TI}$ indices of $0.65 \%$ and $1.73 \%$, respectively, were close to the $0.63 \%(\mathrm{Al})$ and $1.46 \%(\mathrm{TI})$ reported by Arruda et al. (2012) for the meat of Santa Ines feedlot lambs fed Tifton 85 hay and concentrate. These indices connect the pro- and anti-atherogenic acids and indicate the stimulus potential for platelet aggregation, i.e. the low Al and TI indices observed in this trial indicate a larger amount of anti-atherogenic fatty acids and, as a consequence, greater potential for preventing the onset of coronary diseases (Ulbright \& Southgate, 1991).

\section{Conclusions}

Inclusion of mulberry hay at levels of up to $25 \%$ in the concentrate portion of lamb diets increased the concentrations of unsaturated $\alpha$-linolenic, $y$-linolenic, CLA and omega- 3 acids and considerably reduced the omega-6 to omega-3 ratio in their meat; improving its nutritional quality. The results of this trial characterize this forage plant as an important source to manipulate the fatty acid profile and validate its use as an alternative ingredient for improving the nutritional quality of meat from feedlot lambs.

\section{Acknowledgements}

The authors thank the São Paulo Research Foundation (FAPESP) for funding this research (Grant no. 2011/18362-0).

\section{Authors' Contributions}

LGAC and AGSS designed the study, collected and analysed the data, drafted and revised the manuscript. EAO, FAA, VE and NMBLZ designed the study and collected the data. GGPC, GMB and RLV analysed the data and revised the manuscript.

\section{Conflict of Interest Declaration}

The authors declare that there was no conflict of interest.

\section{References}

Arruda, P.C.L., Pereira, E.S., Pimentel P.G., Bomfim, M.A.D., Mizubuti, I.Y., Ribeiro, E.L.A., Fontenele, R.M. \& Regadas Filho, G.L., 2012. Fatty acids profile in longissimus dorsi of Santa Ines lambs fed with different energy levels. Semina. 33, 1229-1240.

AOAC International, 1995. Official methods of analysis. 16th edition. Association of Official Analytical Chemists, Inc., Washington, DC, USA.

Ba, N.X., Giang, V.D. \& Ngoan, L.D., 2005. Ensiling of mulberry foliage (Morus alba) and the nutritive value of mulberry foliage silage for goats in central Vietnam. Livest. Res. Rural Dev. 17, 1-9.

Bamikole, M.A., Ikhatua, M.I., Ikhatua, U.J. \& Ezenwa, I.V., 2005. Nutritive value of mulberry (Morus spp.) leaves in the growing rabbits in Nigeria. Pak. J. Nutr. 4, 231-236.

Banskalieva, V., Sahlu, T. \& Goetsch, A.L., 2000. Fatty acid composition of goat muscles and fat depots: A review. Small Rumin. Res. 37, 255-268.

Belury, M.A., 2002. Dietary conjugated linoleic acid in health: Physiological effects and mechanisms of action. Ann. Rev. Nutr. 22, 505-531.

Bessa, R.J.B., 1999. Revalorização nutricional das gorduras dos ruminantes. In: Proceedings of the Symposium Europeo Alimentación em el Siglo 21, 283-313. (in Portuguese)

Bligh, E.G. \& Dyer, W.J., 1959. A rapid method of total lipid extraction and purification. Can. J. Biochem. Physiol. 37, 911-917.

Bohac, C.E., Rhee, K.S. \& Ono, K., 1988. Assessment of methodologies for colorimetric cholesterol assay of meats. J. Food Sci. 53, 1642-1693.

Bonanome, A. \& Grundy, S.M., 1988. Effect of dietary stearic acid on plasma cholesterol and lipoprotein levels. N. Engl. J. Med. 318, 1244-1247.

Coletta, J.M., Stacey, J.B. \& Ashley, S.R., 2010. Omega-3 fatty acids and pregnancy. Rev. Obstet. Gynecol. 3, 163-171.

Costa, R.G., Cartaxo, F.Q., Santos, N.M. \& Queiroga, R.C.R.E., 2008. Goat and sheep meat: Fatty acids composition and sensorial characteristics. R. Bras. Saúde Prod. Anim. 9, 497-506.

Fernandes, A.R.M., Sampaio, A.A.M., Henrique, W., Oliveira, E.A., Oliveira, R.V. \& Leonel, F.R., 2009. Fatty acids composition and meat quality of Nellore and Canchim young bulls fed sugar cane-based diets with two concentrate levels. R. Bras. Zootec. 38, 328-337.

Ferreira, D.F., 2011. Sisvar: A computer statistical analysis system. Ciênc. Agrotec. 35, 1039-1042.

Jenkins, T.C., Wallace, R.J., Moate, P.J. \& Mosley, E.E., 2008. Board invited review: Recent advances in biohydrogenation of unsaturated fatty acids within the rumen microbial ecosystem. J. Anim. Sci. 86, 397-412.

Kandylis, K., Hadjigeorgiou, I. \& Harizanis, P., 2009. The nutritive value of mulberry leaves (Morus alba) as a feed supplement for sheep. Trop. Anim. Health Prod. 41, 17-24.

Kazala, E.C., Lozeman, F.J., Mir, P.S., Laroche, A., Bailey, D.R. \& Weselake, R.J., 1999. Relationship of fatty acid composition to intramuscular fat content in beef from crossbred Wagyu cattle. J. Anim. Sci. 77, 1717-1725. 
Madruga, M.S., Vieira, T.R.L., Cunha, M.G.G., Pereira Filho, J.M., Queiroga, R.C.R.E. \& Sousa, W.H., 2008. Effect of diets with increasing levels of whole cotton seed on chemical composition and fatty acid profile of Santa Inez (Santa Inês) lamb meat. R. Bras. Zootec. 37, 1496-1502.

Malau-Aduli, A.E.O., Siebert, B.D., Bottema, C.D.K. \& Pitchford, W.S.A., 1997. Comparison of the fatty acid composition of triacyclglycerols in adipose tissue from Limousin and Jersey cattle. Aust. J. Agric. Res. 48, 715-722.

Medeiros, R.M., Albertini, T.Z. \& Marino, C.T., 2015. Nutrição de bovinos de corte: fundamentos e aplicações. In: S.R. Medeiros, R.C. Gomes, D.J. Bungenstab (eds). EMBRAPA Gado de Corte. Brasília, Brazil, 63-76. (in Portuguese)

Mulvihill, B., 2001. Ruminant meat as a source of conjugated linoleic acid (CLA). Nutr. Bull. 26, 295-299.

NRC, 2007. Nutrient Requirements of small ruminants: Sheep, goats, cervids and new world camelids. National Academies Press, Washington, DC, USA, 244-270.

ISO, 1978. Animal and vegetable fats and oils: Preparation of methyl esters of fatty acids. Method ISO 5509. Geneva, CHE, 10-15.

Perini, J.Â.L., Stevanato, F.B., Sargi, S.C., Visentainer, J.E.L., Dalalio, M.M.O., Matshushita, M., Souza, N.E. \& Visentainer J.V., 2010. Ácidos graxos poli-insaturados n-3 e n-6: metabolismo em mamíferos e resposta imune. Rev. Nutr. 23, 1075-1086. (in Portuguese)

Rhee, K.S., 1992. Fatty acids in meats and meat products. In: C.K. Chow (ed). Fatty acids in foods and their health implications. New York, USA, 65-93.

Sanchez, M.D., 2002. Mulberry: an exceptional forage available almost worldwide. Wrld Anim. Rev. 93, 1-21.

Santos-Silva, J., Bessa, R.J.B. \& Mendes, I.A., 2002. The effect of genotype, feeding system and slaughter weight on the quality of light lamb. II. Fatty acid composition of meat. Livest. Sci. 77, 187-194.

Scollan, N., Hocquette, J.F., Nuernberg, K., Dannenberger, D., Richardson, I. \& Moloney, A., 2006. Innovations in beef production systems that enhance the nutritional and health value of beef lipids and their relationship with meat quality. Meat Sci. 74, 17-33.

Simopoulos, A.P., 2002. Omega-3 fatty acids in inflammation and autoimmune diseases. J. Am. Coll. Nutr. 21, 495-505.

Simopoulos, A.P., 2004. Omega-6/omega-3 essential fatty acid ratio and chronic diseases. Asia Pac. J. Clin. Nutr. 20, 77-90.

Tornberg, E., 2005. Effects of heat on meat proteins - Implications on structure and quality of meat products. Meat Sci. 70, 493-508.

Yu, Y. \& Funk, C.D., 2006. Novel aspects of eicosanoid signalling through the use of gene-targeted mice. Scand. J. Nutr. 50, 33-38.

Ulbricht, T.L.V. \& Southgate, D.A.T., 1991. Coronary heart disease: Seven dietary factors. Lancet 338, 985-992.

Willians, C.M., 2000. Dietary fatty acids and human health. Annales Zoot. 49, 165-180.

Vu, C.C., Verstegen, M.W.A., Hendriks, W.H. \& Pham, K.C., 2011. The nutritive value of mulberry leaves (Morus alba) and partial replacement of cotton seed in rations on the performance of growing Vietnamese cattle. Asian-Austral. J. Anim. Sci. 24, 1233-1242. 